\title{
Vlado Popovski
}

\section{THE DIFFERENT FATES OF ALBANIA AND MACEDONIA AT THE LONDON CONFERENCE OF AMBASSADORS 1912-1913}

DOI: $10.2478 /$ seeur-2014-0008

At the time before the First World War, before the opening of the London Conference, the governments of the major European powers established the principle of autonomy of Albania ${ }^{1}$. At the opening of the London Conference on 17 December 1912, at its first session, the Powers decided to create an autonomous and neutral ${ }^{2}$ Albania under the control and guarantee of the European Great Powers and the sovereignty of the Sultan.

Macedonia did not exist at all as a separate issue at the London Conference. The Conference, preparing the peace agreement between the Ottoman Empire and the Balkan allies, specified that Macedonia, as a part of the territories west of the line Enos - Midia, would be ceded to the Balkan countries under their governance.

After the signing of the London Peace Agreement ${ }^{3}$ Macedonia became part of the pie of the neighboring Balkan countries (Bulgaria, Greece and Serbia) which, in turn, by mutual bloody war, divided the territory of Macedonia and determined their mutual borders 4 .

After the termination of the Sultan's sovereignty over Albania on 29 July 1913, Albania gained independence, guaranteed and controlled by the six

1 Балканската война или Руската оранжева книга, София 1914, доц. №. 60 (хереинафтер: Оранжева книга)

2 Оранжева книга, doc. № 34, 37.

3 Лунева Ю. В. Босфор и Дарданеллы. Тайные провокации накануне Первой мировой войны (1908-1914). Москва 2010, pp. 88-94.

4 Саво Скоко, Други балкански рат 1913, Београд 1975 
European powers. Since then, regardless of the difficult "scissors" 5 by which the Great Powers tailored Albanian borders, Albanian statehood has celebrated its hundredth anniversary. Albanians also achieved statehood over Kosovo where the Albanian liberation movement before the Balkan wars was most developed and most dedicated ${ }^{6}$.

Macedonia, after the Balkan Wars, the Bucharest Peace Conference (1913), and the Paris Peace Congress (1919), was divided among the three Balkan countries (Serbia, Bulgaria and Greece) and placed in the nomenclature of the concepts and categories of those countries. From that time forth, to this day, the name of the people and the name of the country (the Republic created in 1944 and independent since 1991) has been denied, as has the name of the language and of the church in the Republic of Macedonia ${ }^{7}$.

What are the factors which created these two different fates, the fates of the Albanian and the Macedonian people, and that of the Albanian liberation movement vis-a-vis the Macedonian movement? After all they are historically and territorially close; they are repressed peoples with parallel liberation movements ${ }^{8}$ parallel both in their programs and their aims; close and cooperative in the fight against almost the same dangers and the same opponents?

In response to this question some reasons and factors can be identified, such as the role of the geopolitical position of Macedonia and of Albania, ethnic and cultural (religious, multiconfessional, and linguistic) composition of the population of Macedonia and Albania, the role and policy of major European powers towards Macedonia and Albania, the impact of the millet

5 Оранжева книга, doc. бр. 63, 71, 78, 79, 80, 83-85, 87, 89-92, 96-97, 106, 108-110, 113-114, 116; Тодороска Катерина, Политичките и културните врски меѓу Македонците и Албанците 1903-1913, Скопје 2003, d. II (documents), doc. 127-129, 131, 136, 138-141, 143-144, 146.

6 See: Абдули Рамиз, Албанското ослободително движење 1908-1910, т. 1, Скопје 2002; Абдули Рамиз, Албанското ослободително движење 1911-1912, т. 2, Скопје 2003; Сенкевич И. Г. Освободительное движение албанского народа в 1905-1912, Москва 1959; Popovski Vlado, Lëvizja Kombëtare Çlirimtare Shqiptare 1830-1912, Tetovë 2012

7 See: Мартис Н. Фальсификация истории Македонии, Афины 1992; Българска национална доктрина, България през XXI век, София 2008; Мирчев Димитар, Балканскиот мегаетникум, националните доктрини на македонските соседи, Скопје 2013

8 Сенкевич И. Г. Освободительное движение албанского народа в 1905-1912, Москва 1959; Истата, Албания в период Восточного кризиса (1875-1881), Москва 1965; Поповски Владо, Македонското ослободително движење до ТМОРО, Скопје 1989; Катарџиев Иван, Сто години од формирањето на ВМРО, Скопје 1993 
system on the profiling of the Albanian and Macedonian liberation movements, on their goals, etc. The policy of the Balkan states (minor states), as well as the policy of the Ottoman Empire itself, towards Macedonia and Albania also constitute causes.

However, the dominant consideration in the complex causes and factors was the policy and the role of the major European powers, because none of the Balkan liberation movements succeeded in their fight for emancipation from the Ottomans and in establishing their own autonomous or independent state. On the contrary, all Balkan countries, despite the effect of the individual national-liberation movements, finally, were established by the power and the authority of the major European states, acting in "concert". This is true with regard to Greek, Serbian, Romanian and Bulgarian statehood ${ }^{9}$. This is also true with regard to the political fates of Albania and Macedonia, despite the fact that they were oriented in different directions.

The battle of the Albanian people and the goals of the Albanian nationalliberation movement were supported by Austria-Hungary as a respected European power, which, along with Russia, was one of the two states directly concerned and involved in Balkan affairs. Behind its eventual protégé, came Germany, and from time to time also the other west European powers (Italy, England and France). Beginning with the Eastern Crisis (1875-1881) until formation of the Albanian state in 1912-1913, the Albanian liberation movement had continual support from the European powers, mainly from Austria-Hungary. This can be seen from the Reichstadt Secret Agreement of June 26 (July 8) 1876 between Austria-Hungary and Russia ${ }^{10}$; from the Secret Convention between Russia and Austria-Hungary signed in Budapest on January 3 (15), $1877^{11}$; from the Secret Agreement between Russia and Austria-Hungary in $1897^{12}$; from the note from the Austria-Hungarian Foreign Minister Count Berchtold of August 13, 1912 ${ }^{13}$; as well as from the decision

9 See: Глог Ричард, Историја Грчке новог века, Београд 2000, pp. 12-49; Павловиќ Стефан, Историја Балкана 1804-1945, Београд 2004, pp. 68-108; Козьменко И. В. Сборник договоров России с другими государствами, 1856-1917, Москва 1952, doc. № 25, pp. 159-175.

10 Козьменко И. В. Сборник договоров России с другими государствами, 1856-1917, Москва 1952, doc. № 22, pp. 144-148.

11 Ibid., doc. № 23, pp. 149-155.

12 Ibid., doc. № 47, pp. 303-308.

13 Жебокрицкий В. А. Болгария накануне балканских войн 1912-1913, Киев 1960, pp. 217-221. 
of the London Conference of Ambassadors in 1912-1913 when Albania was established as an autonomous, that is, as an independent (and neutral) state.

On the other hand attitude the policy of the European Great Powers towards Macedonia was diametrically different. Their policy towards Macedonia, clearly and explicitly, was determined by Russia, whose right to do so was recognized by the other powers, with the exception Austria-Hungary ${ }^{14}$. In relation to Macedonia, from time to time, England became involved, but it also vacillated while Russia remained firm in its positions. In essence, the politics of the great European powers towards the Balkans and Macedonia was modeled by Austria- Hungary and by Russia. Between them there traditionally was consent and agreement concerning the division of zones of influence in the Balkans. When it came to the western Balkans, Bosnia and Herzegovina, Montenegro, Albania and Ionian belts, Austria-Hungary had the advantage. But, when it came to the eastern Balkans, Russia had the advantage ${ }^{15}$. Thus, Macedonia, as a central Balkan country since the middle of the 19th century and especially since the Eastern Crisis (1875-1881), step by step, became a space over whose fate Russia won a dominant role.

Russian Balkan policy became the main variable in the varying political fate of Macedonia. Russia, until the Berlin Congress, included Macedonia in its plans for a great Balkan state, to be a satellite of Russian Balkan policy. In this regard Macedonia was to be a part of the concept of Catherine II for a Great Greece ${ }^{16}$, of the concept of Alexander II for a Great Serbia (the Danube to Mesta ${ }^{17}$ ), and of the concept of Alexander II for a Great (San Stefano) Bulgaria $^{18}$.

After the final confirmation that the western European powers would not allow the creation of a large pro-Russian state in the Balkans, Russia, adopting the concept of small Balkan states, decided to replace its previous model

14 Козьменко И. В. Сборник договоров России с другими государствами, 1856-1917, Москва 1952, doc. № 31, pp. 228-233.

15 See: История XIX века под редакцией Лависса и Рамбо, т. 7-8, Москва 1939

16 Seе: Век Екатерины II. Россия и Балканы, Москва 1998

17 Seе: История XIX века под редакцией Лависса и Рамбо, т. 3, Москва 1939; Записки графа Н. Игнатьева // Исторический вестник, январь CXXXV-CXXXVI

18 Seе: Козьменко И. В. Сборник договоров России с другими государствами, 18561917, Москва 1952, doc. № 25, pp. 159-175; Dedijer Vladimir, Interesne sfere, Beograd 1980 
(more precisely to vary it) with a Balkan Union of small Balkan states (minor states) that would be obliging in relation to the Russian Balkan policy ${ }^{19}$.

To create such an alliance of the Balkan very small states, or Balkan very small beasts, as they sometimes were called because of their mutually hostile and aggressive attitudes, Russian expansion into the Balkans by the occupation of Ottoman Balkan territories had to be promised. Balkan state expansion into Ottoman Balkan territories was, however, burdened with myths about medieval empires, including those of Byzantium, and Serbian Empire of Tsar Dusan and the Bulgarian Empire of Simeon I the Great ${ }^{20}$.

On this basis, their national programs, driven by mythomania, actually overlapped on many Balkan territories, mostly on the territory of Macedonia. Such a reality among the Balkan minor states forced Russian policy to solve two problems: (1) the "appetite" of the Balkan minor states to expand and (2) balancing the expansion by mutual acceptance of each other's boundaries. These questions by their dynamics created the bloody Balkan drama, starting with the Balkan wars and extended into the two world wars. And there are signs that the fireplaces of the hostilities have not been extinguished to date.

However, the new Russian policy, after the Great Eastern Crisis of 18751881, started in 1886 when the new Russian emperor, Alexander III, agreed with the proposal of the prominent and respected diplomat Nelidov, who suggested that Macedonia not to be given entirely to one Balkan country but rather be divided between the three Balkan countries (between Serbia, Bulgaria and Greece). Since this might turn the Greek government of Trikupis in the direction of Russia, Alexander III fully agreed with the proposal of Nelidov ${ }^{21}$.

From that time on, Russia was focused on preparing the conditions for the realization of its Balkans policy, first focusing on the terms for the division of Macedonia among the three Balkan states. In this sense, the first thing that Russian policy did was further fractionalize the Macedonian Orthodox society in three directions.

19 See: Киняпина Н. С. Балканы и проливы во внешней политике России в конце XIX века (1878-1898), Москва 1994, pp. 78-80.

20 АВПРИ. Ф. 151. Оп. 482. Д. 3532. ЛЛ. 122-125

21 Emperor Alexander III wrote on the margins: „Совершенно одобряю“ - see: Киняпина Н. С. Балканы и проливы во внешней политике России в конце XIX века (1878-1898), Москва 1994, pp. 78-80. 
According to the Ottoman Millet system, Greek influence was notably widespread on the territory of Macedonia until the 1880s. Therefore Bulgarian and Serbian influence should be extended and the regions determined.

Starting from the 1880 s, for almost a decade - a decade and a half, Russia has been pressing the central Ottoman government to allow the posting of Exarchate (Bulgarian) metropolites in Macedonia. By the gradual increase in the number of Exarchihal metropolites, Greek influence began to withdraw to the south, thereby, Bulgarian influence sank solid roots in the central part, reaching the western and northern borders of Macedonia ${ }^{22}$.

Splitting the Macedonian population was carried out by a process of rupture and the increasing of confessional-party hatred and conflicts. With time, on that basis, Macedonia became a country ruptured, in which, parts of the same ethnic and religious (Slavic and Orthodox) community struggled and pulled in different directions ${ }^{23}$. This rupture was also deepened by the roles of the Empire itself and the Balkan states concerned.

The Empire, for its own purposes, spent a lot of money and sent many emissaries throughout Macedonia, in order to increase the rupture wherever possible involving the groups in quarrels and hatred ${ }^{24}$. The very small Balkan states, however, also "dipped into" their budgets, bribing numerous prominent categories of the population and sending a whole camarilla of agents, teachers, priests and other persons, posing as protectors of the vulnerable and impoverished population ${ }^{25}$.

Thus, according to the Millet system, the Balkan countries established (in Macedonia ) whole structures of their institutions: churches, schools, municipalities, supporting institutions, agent networks, etc. Through these, the Balkan states and their propaganda through the Exarchate and the Greek Patriarchate, took, in their hands and under their control, the education and upbringing of the younger generation, carrying out the civil affairs (weddings, divorces, custodianship, inheritance and other matters) as well as representing the needs of the people before the Ottoman authorities.

22 See: Кирил, Патриах Български, Българската екзархия в Одринско и Македония след освободителната война 1877-1878, София 1969

23 АВПРИ. Ф. 151. Оп. 482. Д. 1011. ЛЛ. 91-93; АВПРИ. Ф. 151. Оп. 482. Д. 2629. ЛЛ. 262-263; Амфитеатров А. Страна раздора, Санкт-Петербург 1903

24 BOA Rumeli Müfettişliği, Jandarma Müşiriget ve Kumandanlik Evraki 34.3340.3.8

25 Битоски Крсте, Историја на Македонија, Скопје 2003, v. 3, pp. 38-59 
At the beginning of the 1890 s, in that way, Bulgarian influence was also strengthened and expanded, and because of that Russia decided to introduce and establish through the Millet system, Serbian influence in Macedonia. This was done through the Firmilian project. Namely, at the vacate patriarch metropolitan department in Skopje, Russia succeeded in obtaining consent from both the Greek Patriarch and the Sultan to post Firmilijan ${ }^{26}$ as Metropolitan of Skopje. He, as a Serb, began to establish a Serbian bishopric and register the Serbian population. So, (in addition to the Greek and Bulgarian) a Serbian millet ${ }^{27}$ was also registered in Macedonia on the same Slavic and Macedonian Orthodox body; often from parts of the same genera, families, and households in the same cities and in neighboring or even in the same villages. All these changes were made by the 1890 s when, in the meantime, more unexpected political and revolutionary events happened in Macedonia.

These included the Vrhovist Melnik provocation, for the so-called Melnik uprising $^{28}$, as well as the grand Vinica affair ${ }^{29}$, on the occasion of which it was demonstrated that all of Macedonia was covered with a network of revolutionary committees preparing the population for an uprising against the Empire to win full political autonomy for Macedonia. This surprised both the government and the Russian diplomacy. The latter, while working on fracturing the Macedonian (Slav and Orthodox ) community, had not expected the formation of a general Macedonian revolutionary movement with unique general political goals and the ability to unite the masses for such purposes.

The Macedonian revolutionary movement had opposite goals from those of Russian Balkan policy and Russian intentions towards Macedonia, and as a result Russian diplomacy, both at the center, and in the field, took a complex, long-term and drastic measures against the Macedonia Revolutionary Organization and against its political goals ${ }^{30}$ which were independent from

26 АВПРИ. Ф. 151. Оп. 482. Д. 2629. ЛЛ. 262-263; АВПРИ. Ф. 151. Оп. 482. Д. 3603. ЛЛ. 91-93; АВПРИ. Ф. 151. Оп. 482. Д. 3532. ЛЛ. 321-322; АВПРИ. Ф. 151. Оп. 482. Д. 1014. ЛЛ. $28-29$

27 АВПРИ. Ф. 151. Оп. 482. Д. 1011. ЛЛ. 187-188 (The Russian representative in Belgrade, Muravjov Apostol Korobin on September 13/26, 1903, informed about the gratefulness expressed by the Serbian Foreign Minister Kaljevikj for the merits of Russia in the recognition of "Serbian" nationality in Macedonia. The Sultan, in September 1903, by a decree, recognized such nationality in Macedonia.)

28 Битоски Крсте, Историја на Македонија, Скопје 2003, v. 3, pp. 174-178

29 Ibid, pp. 224-226.

30 that the Bulgarian duke and the Bulgarian government had no impact on the Internal Macedonian Revolutionary Organization was also confirmed by the Russian political representative in Sofia Bahmetjev - see: АВПРИ. Ф. 151. Оп. 482. Д. 1008. Л. 33; 
those of the Bulgarian court and the Bulgarian government. Russian diplomats on the ground received explicit instructions from the Russian Foreign Minister Count Muravyov. He, in 1898, on the occasion of the Crete events and the expectation of new ventures by the Macedonian committees, dictated to his diplomats on the ground that they should warn the Macedonian committee members not to do anything that would disturb the peace, because the key to the solution for Macedonia was located in St. Petersburg, not in the Balkans. At the same time he told the diplomats to warn the Macedonians that if they raised a rebellion they could not hope for sympathy or support from Russia. On the contrary, in such a case, the Russian administration would be forced to offer the Turkish authorities full freedom to annul, at root, the revolutionary thoughts of the Macedonians. ${ }^{31}$ That threat was even more forcefully communicated by the Russian diplomatic representative in Sofia, Bahmetjev. He explicitly told Boris Sarafov to resign from running the Supreme Committee and to stop procuring weapons and training young people for the bands in Macedonia, because otherwise Macedonian Organizations would be faced with the final measures that would be supported by Russia. Sarafov refused to comply so Bahmetjev drafted that threat which after 1898, and especially after 1902-1903, actually began to be realized.

Namely, Bahmetjev stressed: " ... That being so, both your organization here (referring to the Supreme Committee) and that one there (referring to the Revolutionary Organization in Macedonia) would go into dust and ashes." ${ }^{32}$

After the Gorna Dzhumaja Uprising in 1902 and after the realization that a general uprising had been planned in Macedonia for the next spring, Russian diplomacy took systematic measures to obstruct the Macedonian liberation movement and to impose its policy for the future division of Macedonia. Therefore Count Kapnist, the Russian ambassador in Vienna, proposed, and the Minister accepted the following:

(1) To avoid violation of the division of vilayets and establishment, from the vilayets in Macedonian, a sole province of Macedonia;

Спространов Ефтим, Дневник, София 1994, pp. 205. Regarding the measures undertaken by Russia see: АВПРИ. Ф. 151. Оп. 482. Д. 2629. ЛЛ. 202-205; АВПРИ. Ф. 151. Оп. 482. Д. 2623. ЛЛ. 129-131; АВПРИ. Ф. 151. Оп. 482. Д. 1011. Л. 150.

31 Дракул Симон, Македонија меѓу автономијата и дележот, Куманово 1995, v. 1, pp. 259-260.

32 Memories of Boris Sarafov - in: Освободителното движение в Македония и Одринско, спомени и материали, т. 1, София 1983, p. 58. 
(2) To avoid the use of the name Macedonia but to use the name "The Three Vilayets" by listing their particular names;

(3) To avoid the use of the term General-Gubernator which, in connection with the future planned reforms, has been commonly used (for example by England) and instead of it to use the term Inspector General;

(4) To avoid insisting on establishing a Central Council for the three vilayets as this term is associated with the formation of a political unit that was not under the plan;

(5) To institute reform in the names of millets by including also the Serbmillet (in addition to the Bulgar - millet and Rum - millet);

(6) The Official language in the vilayets, in addition to Turkish, to be the language of the majority Orthodox group, by the name of millet ( Serbian, Bulgarian and Romaean i.e. Greek). ${ }^{33}$

After the relevant secret telegram of Count Peter Kapnist, dated 17 November 1902, Russian Foreign Minister Count Vladimir Lamzdorf, on 7 February 1903, sent a secret telegram to his Plenipotentiary Minister Prince Urusuv, Russian Ambassador in Paris ${ }^{34}$, to inform Delkase, the French foreign minister, that it was agreed with Count Goluchowski, from then on to avoid addressing Macedonia by the name Macedonia instead using the name of "Three Turkish Vilayets" by stressing the name of the vilayet, and to rename the Macedonians the "Christians of the Three Turkish Vilayets" because Lamzdorf did not consider the Macedonians as a nation that had the right to statehood.

After this act, Russia persuaded the Sultan to ban the use of the name Macedonia and instead, in the acts and communications of the Vilayet authorities, to use only the name of the particular Vilayet. The Sultan issued such an order in early April $1903^{35}$.

In the summer of 1903, when it became clear that the Internal Macedonian Revolutionary Organization would raise a rebellion, Count Kapnist on 18 June proposed the following drastic measures: (1) the way out of the vicious circle consists of the final destruction, in the three vilayets, of the Revolutionary

33 АВПРИ. Ф. 151. Оп. 482. Д. 2629. ЛЛ. 198-201

34 АВПРИ. Ф. 151. Оп. 482. Д. 1008. ЛЛ. 84-85

35 Стојановски Александар, Македонија под турска власт, Скопје 2006, pp. 317-318 
Organization; (2) it is particularly dangerous to mention Article 23 of the Treaty of Berlin. It would upset the Empire and would provide the basis for the Revolutionary Organization to consider that concessions were made in terms of its requirements.

Following these proposals Count Kapnist communicated the following sensitive information and assessments: (1) Such a pogrom was carried out also to that point, and estimated that the work will be completed in 2 to 3 months and (2) that although there was no doubt that the persistence and toughness of the Revolutionary Organization have exceeded all expectations ${ }^{36}$.

After the Ilinden uprising Russia supported Turkish authorities in their merciless clash with the leaders and members of the Revolutionary Organization, and following the uprising to continue to destroy them using special units (so-called flying battalions). By 1907-1908, under the pretext of destroying the Macedonian Revolutionary Organization, over 3000 distinguished and eminent Macedonians were liquidated. Besides such killings the companies of the Revolutionary Organization were chased, not only by government units, but also by Greek and Serbian companies that were invited to come to Macedonia and were tolerated by Turkish authorities at the time when they were carrying out pogroms on the population of "the other millets"37. A kind of elitocide was carried out in the Macedonian Slavic community, in a wide area all over Macedonia. The surrounding states, with their own companies and supporters, tried to create much wider territories pursuant to Article 3 of the Maesteg reforms that, essentially, requested the establishment of new administrative territories where "the three" Macedonian millets ("Bulgarian", "Serbian" and "Greek") derived from the unique Macedonian Slav ethnic and linguistic body. ${ }^{38}$

36 АВПРИ. Ф. 151. Оп. 482. Д. 1013. ЛЛ. 485-487; АВПРИ. Ф. 151. Оп. 482. Д. 2629. ЛЛ. 34-36, 189-190; АВПРИ. Ф. 151. Оп. 482. Д. 1008. Л. 33; АВПРИ. Ф. 151. Оп. 482. Д. 564. Л. 30; АВПРИ. Ф. 151. Оп. 482. Д. 2633. Л. 1; АВПРИ. Ф. 151. Оп. 482. Д. 1475. Л. 324

37 See for example, Австриски документи за историјата на македонскиот народ 19051906, Скопје 1977, doc. бр. 1-10, 14-15, 27-28, 31-34, 38-39, 41-45, 50, 58, 61, 66, 69-71, 78-81, 86-89, 91-94, 101, 103-105, 122, 126

38 For example, in the Skopje region, the village Ljubaci - "Bulgarians ", v. Kuceviste "Serbs ", v. Mirkovci - half " Bulgarians " half - "Serbs". Or in Skopje the three sons of Hadzi Trajko: one used to go to a Bulgarian school, the second - to a Greek, and the third - to a Serbian school, and they were mannered and registered in the relevant statistics as "Bulgarian", "Greek " and "Serb " .In Prespa v. D. Dupeni - "Greeks", v. Ljubojno (2 km away) - "Bulgarians", v. Brajcino (1.5 km away from the village Ljubojno ) - " Greeks ", etc. And they all, in Skopje, in Prespa, and elsewhere in Macedonia were relatives, spoke the same language and alike. 
The "crushing" of the Macedonian ethnic body and the Macedonian Revolutionary Organization took on particular importance in the new circumstances in the Balkans. Namely, in the summer of 1909, Turkey began to come closer to Germany and Austria- Hungary, and in December 1909 asked for a military alliance with Austria-Hungary. Thus, they made it clear that they did not accept the plans of Russia, "pushed" by the Russian ambassador in Constantinople Charikov which hoped to tie the Balkan minor states to Russia ${ }^{39}$. Within the next one to two years, Turkey fully entered the orbit of the German bloc, giving a series of concessions, including continued construction of the so-called Baghdad railway to the shores of the Persian Gulf.

As the German-Austrian bloc broke through towards Central Asia and increased its influence in the Turkish Empire, Russia stood even more firmly behind the idea of establishment a union of Balkan countries and for their expansion in the Balkans removing the Empire from its Balkan possessions. Both England and France supported this Russian policy because their interests were endangered by the breakthrough of Germany towards the Ottoman Empire and towards their zones of interest in Asia.

However, that policy, logically, assumed the division of the Balkan Turkish territories, including the territory of Macedonia, by the future Balkan allies,.

From 1909, and especially since March $1910^{40}$ onwards, until the conclusion of the Balkan Union in 1912, Russia negotiated with Bulgarian and Serbian state and government leadership with regard to the division of Macedonia. At that time and in that regard, the activities of Russian diplomacy, in the capital and in the Balkans, became continuous and intensive, so that the conclusion of the Balkan alliance and the planned division of Macedonia appeared, primarily, as a result of its efforts. ${ }^{41}$

Within the whole procedure of negotiation Macedonia was the quarry, tailored and shared in every detail. Among the facts recorded was also the curious relationship between the Russian ambassador in Belgrade (Gardvig)

39 Rossos Andrew, Među balkanska rivalstva i ruska vanjska politika 1908-1914, Zagreb 1992, str. 17-78

40 Жогов В. П. Дипломатия Германии и Австро-Венгрии и первая балканская война 1912-1913, Москва 1969, pp. 3-84.

41 Rossos Andrew, Među balkanska rivalstva i ruska vanjska politika 1908-1914, Zagreb 1992, str. 17-78; Жебокрицкий В. А. Болгария накануне Балканских войн 19121913, Киев 1960, pp. 161-184; Россия и славяне, Балканские исследования, Москва 1992, pp. $188-200$ 
and the Russian ambassador in Sofia (Nekljudov) who quarreled over some Macedonian village "dragging" it first to Serbia, then to Bulgaria.

However, the final line of partitioning Macedonia by Bulgaria, Greece and Serbia did not go as was planned (with Russian assistance) and was not peaceful. To the contrary, the procedure of dividing Macedonia occurred through a bloody drama which generated new and vast mutual hatred. It awakened the " the small beasts" in the mutual relations of the Balkan states.

As a result of the Balkan Wars and the Bucharest Peace Conference (1913), and the Paris Peace Treaty (1919), Macedonia and the Macedonian issue were deleted from the official nomenclature and from the geographic, ethnic, and political concepts and categories in the system of international political relations between the two world wars. Until 1944, that is, 1991 when the people of Macedonia themselves established their federal, that is, their independent statehood, these concepts and categories could not establish their identity ${ }^{42}$; regardless of the prolonged struggle and the victims of two Macedonian generations. The consequences of the fierce fate of Macedonia even today finds testimony in the status of the Republic of Macedonia and in its acceptance in the European community of the states.

All this (hi)story demonstrates no small difference between the fates of Macedonia and Albania, and between that of the Macedonian and the Albanian movements.

42 Even in the "Little Larus" of 1936, regarding the term "Macedonia" and "Macedonian," one cannot find anything except "Macedonian salad" which is like mixed vegetable salad. 
$* * *$

Vlado Popovski is professor at the Law Faculty, Ss. Cyril and Methodius University, Skopje and a Macedonian politician. He was Minister for Defence, Minister for Justice as well as the first Director (Founder) of the Macedonian Intelligence Agency. In 1991 he was a member of the team which wrote the Constitution of the Republic of Macedonia. He is author of more than 120 scientific papers. 